\title{
リピドミクスの分析技術と将来展望
}

\section{The Analytical Technique and the Future Vision for the Lipidomics}

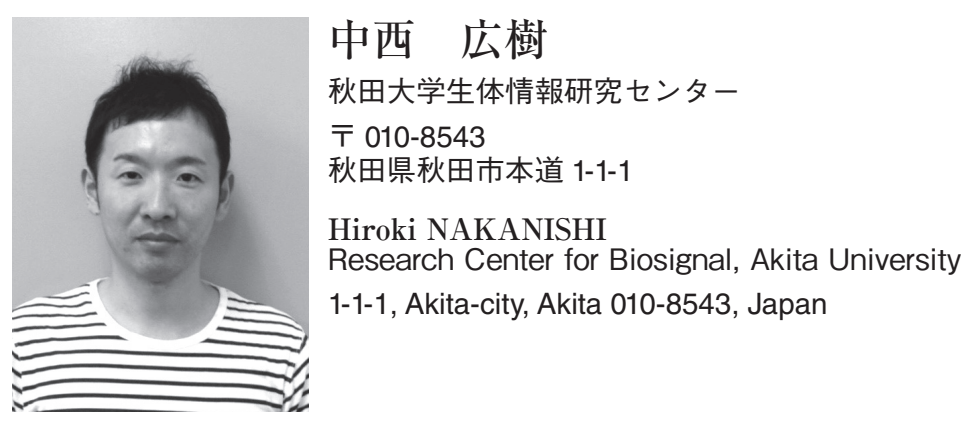

論文要旨：脂質は夕ンパク質, 糖質と並んで生体を構成する重要な成分であり, 生体内において生体膜構 成成分, エネルギー源, 生理活性分子など極めて重要かつ多彩な機能を担っている。古くから脂質成分の解 析には, 薄層クロマトグラフィー（TLC）や液体クロマトグラフィー（LC）, ガスクロマトグラフィー（GC） などの種々のクロマトグラフィー法が汎用されてきた。しかし，これらの分析法はある分子群にターゲット を絞った場合には有効であるが, 微細な構造（sn-1, 2 脂肪酸側鎖など）の違いを解析するのは難しく, 何よ り分析に nmol オーダーの試料を必要とした。しかし, 近年の高感度かつ定量性に優れた質量分析法の開発 により, リン脂質の極性基や脂肪酸側鎖の組合せを含めた分子種レベルでの網羅的解析，ならびに微量検体 での分析が可能となってきた。この脂溶性代謝物を網羅的に解析する研究は, リピドミクスという総称で呼 ばれる比較的新しい研究分野である。我々は, 質量分析法を駆使し，これまで追うことのできなかった生体 内の脂溶性代謝物を網羅的かつ特異的に捉えることで, 生命現象の一端を解明することを目指している。リ ピドミクスは, 細胞や生体内における多数の脂溶性代謝物の変化を, バイアスをかけない手法により網羅的 に探索し, 生命現象を包括的に理解しょうとする研究である。仮説検証のみならず, 網羅的解析により新た な仮説が提唱され，予想もしていなかった大発見をもたらす可能性を秘めている。本総論では, リピドミク ス分析技術とその将来展望について紹介したい。

\begin{abstract}
Lipids has very important and various functions in the body. For examples, lipids are the major constituents of cellular membranes and the most efficient source of energy in living organisms. In addition, lipid molecules also work directly as bioactive molecules in immune self-defense and the maintenance of homeostasis. Traditional techniques such as thin layer chromatography, liquid chromatography and gas chromatography are widely used for lipid analysis. However, these methods are difficult for the analysis of molecular species and they require at nanomolar levels of sample. In recent years, because of the development of mass spectrometry technology, analytical methods for quantifying lipids and their metabolites have led to progress in the number of detectable molecular species and their sensitivity. This analytical technique is called the lipidomics. Lipidomics is an emerging field to investigate the structures, functions and dynamic changes of lipids in cells, tissues or body fluids. We aim at the elucidation of a biological phenomenon by global and/or specific comprehension of biological lipids using lipidomics. In this review, we present the analytical technique and the future vision for lipidomics.
\end{abstract}

Key words: lipid, lipidomics, mass spectrometry, bioactive molecule 


\section{1 はじめに}

脂質は生命を包み，区画する生体膜を構成する細胞の 基本構成要素であり，エネルギー源，生体膜としての役 割に加え, 生理活性物質やその前駆体として働く多彩な 役割を担う生体分子である。よって脂質分子の多様性, 生理機能を理解することは, 生命秩序の原理を知る上で 極めて重要である。脂質は核酸とならぶ根源的な生体物 質であるが, 両者の研究進展には大きな違いがある。遺 伝子については, 1990 年代のヒトゲノム計画推進の前 後から今日に至るまで, 増幅法, 配列決定法, 発現解析 法の技術革新が次々とおこり，研究手法が一般化されて いる。実際，多くの生物のゲノム配列が解明され，その 情報をもとに，有益なタンパク質を大量発現し利用する など，生物が持つ遺伝子は資源として活用されている。 一方，脂質に関してはその水に溶けない物性，ゲノムに 直接コードされない理由から，科学技術が進歩した現在 でも解析し難い対象とされ, 一部の生命科学研究者が, それぞれの経験に基づいた，いわば職人芸を駆使して， 各論的に課題に対峙してきた。

本総論では, 生命科学においてゲノム, プロテオーム に続くオミクス研究として世界的に注目されているリピ ドームの解析手法（脂質メタボローム解析やリピドミク スなど様々な総称で呼ばれる）についてその概念や方法 論, さらには今後の医療応用への期待とその課題などに
ついて論じたい。

\section{2 リピドミクスの分析手法}

リピドミクス解析のフローチャートを Fig. 1 に示す。 大きく(1)サンプルの前処理, (2)分析と (3)その解析に分か れる。それぞれの詳細については後述するが, 大事なこ とは目的に沿った抽出法と分析法を選択することであ る。

\section{$2 \cdot 1$ 脂質分析の変遷}

「脂質は扱いが難しいそうなので手が出せない」とい う話をよく聞く。確かに脂質の中には，水溶液中での半 減期が 1 分に満たない極めて不安定な分子が存在する し, マウスの臓器から回収しようとしても抽出が容易で ない分子も多い。さらに, 臓器を摘出しようとマウスを 解剖した瞬間に急激に産生する分子もある。脂質解析で 重要なことは, 研究対象とする脂質がどのような性質を もっているかを知り, その性状に適した方法を取ること だと思う。

古くからリン脂質成分の解析には，薄層クロマトグラ フィー（TLC）や液体クロマトグラフィー（LC），ガス クロマトグラフィー（GC）などの種々のクロマトグラ フィー法が汎用されてきた。しかし，これらの分析法は ある分子群にターゲットを絞った場合には有効である が, 微細な構造 $(s n-1,2$ 脂肪酸側鎖など）の違いを解析 するのは難しく，何より分析に nmol オーダーの試料を

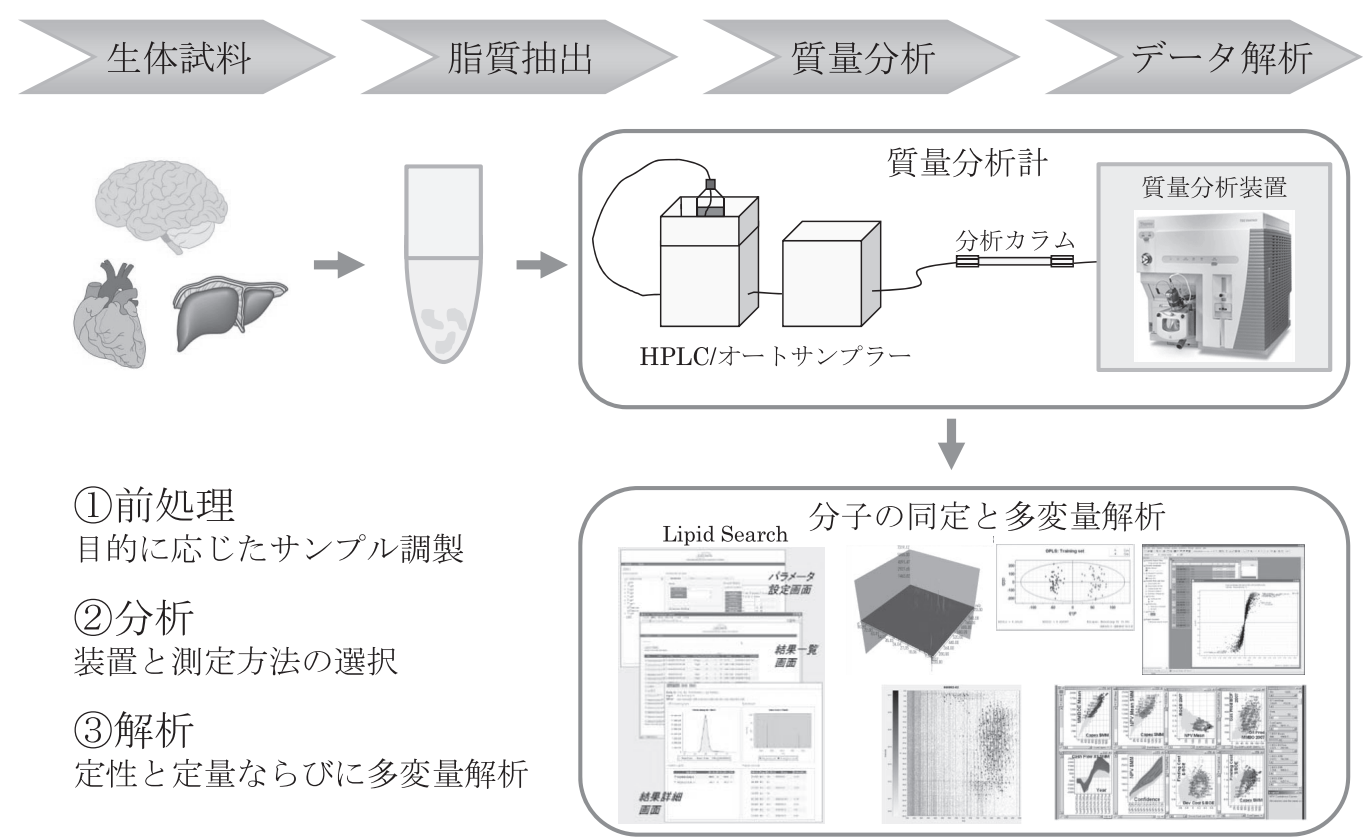

Fig. 1 リピドミクス解析のフローチャート。脂質分子は量的に多い分子と少ない分子とのダイナミックレンジが広いため, 目的 に応じて最適なサンプル調製と質量分析手法を選択する必要がある。さらに，得られた膨大なデー夕から有用な結論を導 くために「データマイニング」が重要となる。リピドミクスで最もよく用いられている多変量解析手法は, 探索的デー夕 解析（主成分分析や階層クラスター解析など）であり，その目的は膨大な量のデータの特性を調査し，デー夕が含んでい る情報の内容を判断することにある。 
必要とした。しかし，質量分析（MS），特にエレクトロ スプレーイオン化 (ESI)/MS による測定が実用化され た 1990 年代半ば以降, 脂質の解析は急速に発展してき た。この脂質を網羅的に解析する研究は, 2000 年以降 になりリピドミクスという総称で呼ばれるようになっ た。近年, リピドミクスをキーワードとした論文は右肩 上がりで増えている（Fig. 2）。実際にリピドミクス技術 が活用されている論文数は, Fig. 2 で示した数の数倍は あると思われ，その注目度の高さがわかる。

\section{$2 \cdot 2$ リピドミクスによる網羅的解析の概念}

リピドミクスの対象となる脂質は，疎水性や極性の高 いもの，低いものなど非常に物性の異なる分子が存在す る。そのため, 生体試料からの抽出方法によってはある 特定の物性を同じくする分子群に偏りのあるサンプルが 調製される。つまり, 抽出方法, 精製方法や分析カラム などに何を選択するかで分析対象とする脂質分子が異 なってくるということである。故に対象を定めない網羅 的手法であっても，ある条件下で抽出，精製したサンプ ル中に含まれる分子群を, その存在量の多い順からでき るだけもれなく解析しているにすぎない。逆に，複数の 抽出方法を組み合わせることによりほとんどの脂質分子 を含む抽出物を得ることは可能だが，脂質は共存する分 子ごとに存在量のダイナミックレンジが違いすぎるため 含有量の小さい分子やイオン化の効率の悪い分子は検出 するのが難しくなる。以上のことより, リピドミクスで いう網羅的というのは大小あるにしろ，ある程度測定対 象分子をカテゴライズしたものになっていることが多

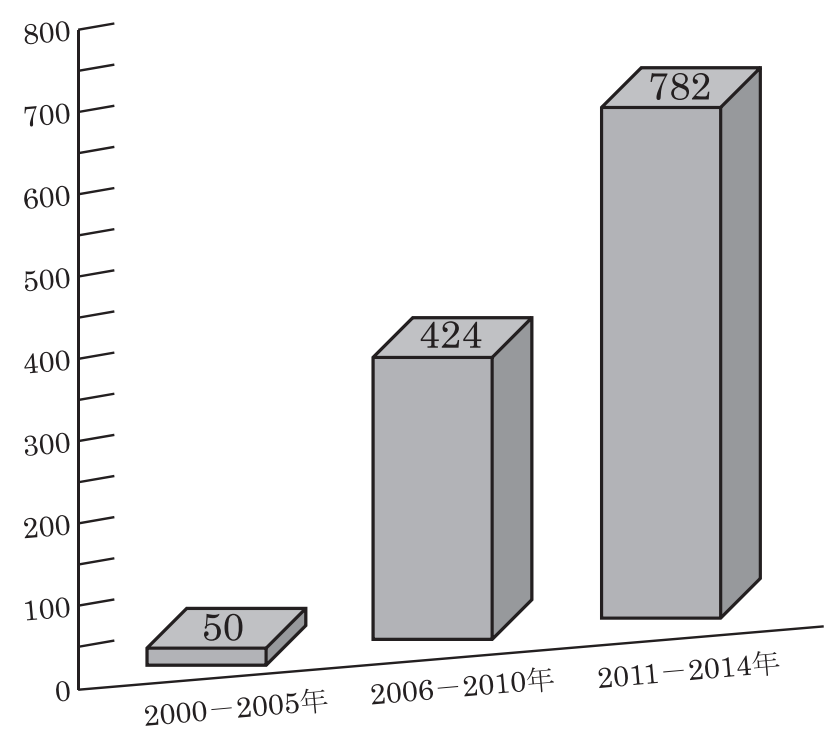

Fig. 2 リピドミクス研究の注目度。リピドミクスという単 語が初めて使われたので 2003 年であり, 年々右肩上 がりで論文数が増えている。グラフの論文数は世界 最大規模の書誌・引用データベースである Scopus で 調べたものである（平成 26 年 5 月末調べ）。 w。

\section{$2 \cdot 3$ 脂質の抽出・精製法}

脂質は生体内で, タンパク質などの生体物質と疎水結 合, 水素結合, イオン結合などで相互作用しながら存在 する。従って脂質の抽出には, それらの相互作用を絶つ 目的で, メタノールなどの極性溶媒と, 脂質を可溶化す るクロロホルムなどの非極性溶媒の混合液が用いられ る。動物藏器の場合は, あらかじめ緩衝液中でホモジナ イズしておくか, 抽出する有機溶媒存在下でホモジナイ ズする必要がある。中性脂質やリン脂質を含む総脂質の 抽出にもっとも汎用さえている方法として Bligh\&Dyer （BD）法がある。しかし， BD 法は中性条件で用いると リゾリン脂質や糖脂質などの極性の高い脂質は水層に逃 げ回収率は低くなる。一方, 塩酸酸性条件下ではリゾホ スファチジルコリン（LPC）の 2〜 4\%が加水分解を起 こし, LPCの分解物としてリゾホスファチジン酸 (LPA)

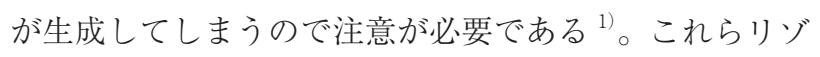
リン脂質や糖脂質などを抽出したい場合には変法が用い られている ${ }^{2)}$ 。また, 有機溶媒を多量に使用するが, 臓 器からの脂質の回収率に優れる方法として Folch 法もよ く使われている ${ }^{3)}$ 。さらに, 抽出した総脂質を分離・精 製する方法として, 溶媒に対する各脂質の溶解度の差を 利用して分別する溶媒分画法や, クロマトグラフィー法 （特に不純物を除去しサンプルを濃縮する目的の分離・ 精製方法を固相抽出法という）がある。個々の抽出・精 製方法については文献を参照して頂きたい ${ }^{3,4)}$ 。

\section{$2 \cdot 4$ 試料導入法とカラム・溶媒選択による溶出順序}

試料の導入法には, あらかじめ溶媒に試料を溶かし込 んでシリンジポンプからダイレクトに質量分析計に注入 するインフュージョン法や，ポンプに接続したインジェ クターを用いたフローインジェクション法などがある。 シリンジポンプは主に機器のキャリブレーションや性能 チェックのための試料測定に使用される。フローイン ジェクションは後述する（2-7-2）プレカーサーイオンス キャン (precursor ion scanning, Pre) やニュートラル ロススキャン (neutral loss scanning, NL) などのトリ プルステージ型質量分析計で測定可能な MS/MS 測定法 と組み合わせると有効である。これら直接注入法は, 多 数のサンプルを短時間で測定できる利点があるものの, ESI/MSにおいて最も懸念されるイオンサプレッション 効果は受けやすい。言い換えれば, 直接注入法では微量 成分の測定は極めて困難となる。よって微量成分を測定 するには，LCなどによる分離法と組み合わせてイオン サプレッション効果を低減させることが必要となる。脂 質の分析手法として最も実績のある TLCと同じ分離 モードを有する順相 LC（NPLC）/MS 法は，以前から利 
用されてきているが，近年では感度や再現性において優 れている逆相 LC (RPLC)/MS 法が微量脂質解析の有効 手段として活用されるケースが多い。脂質（特に酸性リ ン脂質）分析では, 一番の問題である吸着を抑えるため に，金属含有量の少ないカラムやインジェクター部分に 非金属製のイナート材質を用いるのが良い。さらに，あ らかじめカラムを EDTA 等のキレート剤で前処理する ことで吸着を軽減することができる。以下に順相カラム と逆相カラムによるリン脂質の分離の特徴を解説する。

\section{$2 \cdot 4 \cdot 1$ 順相カラムによる分離パターン}

順相カラムを用いた分離では，脂質は極性基の疎水性 の高い分子から低い分子へと順に溶出される。トリグリ セリド（TG）や遊離脂肪酸（FA）などの中性脂質が最 初に溶出した後にホスファチジルグリセロール $(\mathrm{PG})$, ホスファチジルイノシトール (PI), ホスファチジン酸 （PA）などの酸性リン脂質が溶出し，次いでホスファチ ジルエタノールアミン ( $\mathrm{PE})$, ホスファチジルセリン (PS), ホスファチジルコリン (PC), スフィンゴミエリ ン（SM）が溶出する。リゾリン脂質はそれぞれ同じ極 性基を有するリン脂質の直後に溶出する。ただし, 溶出 順序は溶媒条件によって変わる。今回記述したデータの 溶媒条件は，共に $0.1 \%$ ギ酸アンモニウムを含むアセ卜 ニトリル／メタノール (2: 1), pH6.4（溶媒 A）とメ タノール / 水 $(2: 1), \mathrm{pH} 6.4$ (溶媒 B ) のグラジュエン トである。

\section{$2 \cdot 4 \cdot 2$ 逆相カラムによる分離パターン}

逆相カラムの場合は, 順相カラムとは逆に疎水性の低 い分子から疎水性の高い分子へと順に溶出される。脂肪 鎖の鎖長が長い程保持時間は長く，脂肪鎖長が同じ分子 種の場合，不飽和度が高くなると分子の疎水性が低くな り保持時間は短くなる。また, 同じ質量電荷比 $(m / z)$ をもつ分子の場合, $s n-1$ と $s n-2$ がともに不飽和脂肪鎖 であるものは最も早く，不飽和脂肪鎖と飽和脂肪鎖を持 つ分子種の場合は, 飽和脂肪鎖の炭素数が小さいほど早 く溶出してくる傾向にある。ただし，これらも溶媒条件 やカラムの種類によって溶出順序は変わる。

\section{$2 \cdot 5$ 脂質分析に有効な MS の種類}

ESI はフロー系のシステムである LC やキャピラリー 電気泳動 $(\mathrm{CE})$ とオンラインで接続して使用できるため, 脂質分析のイオン化には ESI が沉用されている。Table 1 に脂質分析において ESI と組み合わせて使用される有 効な質量分析装置とその特徵をまとめた。LC との組み 合わせにおいて, 飛行時間型（TOF）は分解能が高く, スキャンスピードも速いため F ast LCが利用可能であ り, ターゲットを絞らない網羅的解析に有効である。イ オントラップ型は分解能こそ高くはないが, MS/MSに 加え, MS/MS/MS などの多段階 MS/MS が可能であり, 分子種同定には最適である。トリプルステージ型は構造 特性を生かした特異的測定法であるプレカーサーイオン スキャンやニュートラルロススキャン, さらには個別分 子のみを検出するため特異性のみならず定量性において もすぐれている多重／選択反応モニタリング（multiple reaction monitoring, MRM/selected ion monitoring, SRM）といった種々の MS/MS モードが使えるため, リン脂質分析において最も汎用されている質量分析計で ある。

\section{$2 \cdot 6$ イオン化のパターン}

リン脂質は極性基の違いにより，正イオンモードで検 出しやすい分子と, 負イオンモードで検出しやすい分子 がある。一般に正イオンモードでは，PCやPEはプロ トン化分子として検出されるが, PI は検出されにくい。 しかし，溶媒中にアンモニアを加えておくとアンモニウ ム付加イオンとして検出される。逆に正イオンモードで 検出されやすかった PC は負イオンモードでは，ほとん ど検出されず，溶媒中にギ酸を加えることでギ酸付加イ オンとして検出される（酢酸添加では酢酸付加イオンで 検出）。どちらのモードでもイオン化しにくい中性脂質 も正イオンモードではアンモニウム付加イオンとして, 負イオンモードではギ酸付加イオンとすることで十分に 検出が可能となる。Table 2 に各脂質クラスのイオン化 パターンをまとめた。この正の分子量関連イオンと負の 分子量関連イオンの $m / z$ は各リン脂質の同定に非常に 重要となる。

Table 1 脂質の分析に有効な質量分析装置とその特徵

\begin{tabular}{|l|l|}
\hline トリプルステージ型 & $\begin{array}{l}\text { マルチファンクショナルな LC/MS が可能 } \\
\text { 種々の MS/MS モードが使える }\end{array}$ \\
\hline 四重極 - TOF 型 & $\begin{array}{l}\text { 分解能が高いため MS/MS の S/N がよい } \\
\text { スキャン時間が短いため Fast LC が可能 }\end{array}$ \\
\hline 四重極-イオントラップ型 & $\begin{array}{l}\text { 自動 MS/MS 解析が可能 } \\
\text { MS ができる }\end{array}$ \\
\hline FT-ICR -イオントラップ型 & $\begin{array}{l}\text { 分解能が非常に高いためミリマス分析が可能 } \\
M^{\mathrm{n}} \text { ができる }\end{array}$ \\
\hline
\end{tabular}


Table 2 脂質のイオン化パターン（溶媒にギ酸アン モニウムを用いた場合)

\begin{tabular}{|c|l|l|}
\hline & \multicolumn{1}{|c|}{ 正イオン } & \multicolumn{1}{|c|}{ 負イオン } \\
\hline $\mathrm{PC}$ & $+1[+\mathrm{H}]$ & $+45[+\mathrm{HCOO}]$ \\
\hline $\mathrm{LPC}$ & $+1[+\mathrm{H}]$ & $+45[+\mathrm{HCOO}]$ \\
\hline $\mathrm{PAF}$ & $+1[+\mathrm{H}]$ & $+45[+\mathrm{HCOO}]$ \\
\hline $\mathrm{SM}$ & $+1[+\mathrm{H}]$ & $+45[+\mathrm{HCOO}]$ \\
\hline $\mathrm{PE}$ & $+1[+\mathrm{H}]$ & $-1[-\mathrm{H}]$ \\
\hline $\mathrm{LPE}$ & $+1[+\mathrm{H}]$ & $-1[-\mathrm{H}]$ \\
\hline $\mathrm{Cer}$ & $+1[+\mathrm{H}]$ & $+45[+\mathrm{HCOO}]$ \\
\hline $\mathrm{Sph}$ & $+1[+\mathrm{H}]$ & $+45[+\mathrm{HCOO}]$ \\
\hline $\mathrm{DG}$ & $+18\left[+\mathrm{NH}_{4}\right]$ & $-1[-\mathrm{H}]$ \\
\hline $\mathrm{MG}$ & $+1[+\mathrm{H}]$ & $+45[+\mathrm{HCOO}]$ \\
\hline $\mathrm{FA}$ & $+18\left[+\mathrm{NH}_{4}\right]$ & $+45[+\mathrm{HCOO}]$ \\
\hline $\mathrm{PI}$ & $+18\left[+\mathrm{NH}_{4}\right]$ & $-1[-\mathrm{H}]$ \\
\hline & $-1[-\mathrm{H}]$ \\
\hline
\end{tabular}

\begin{tabular}{|c|c|c|}
\hline & 正イオン & 負イオン \\
\hline LPI & $\begin{array}{l}+1[+\mathrm{H}] \\
+18\left[+\mathrm{NH}_{4}\right]\end{array}$ & $-1[-\mathrm{H}]$ \\
\hline PA & $+18\left[+\mathrm{NH}_{4}\right]$ & $-1[-\mathrm{H}]$ \\
\hline LPA & $\begin{array}{l}+1[+\mathrm{H}] \\
+18\left[+\mathrm{NH}_{4}\right]\end{array}$ & $-1[-\mathrm{H}]$ \\
\hline $\mathrm{cPA}$ & $+18\left[+\mathrm{NH}_{4}\right]$ & $-1[-\mathrm{H}]$ \\
\hline PG & $+18\left[+\mathrm{NH}_{4}\right]$ & $-1[-\mathrm{H}]$ \\
\hline LPG & $+18\left[+\mathrm{NH}_{4}\right]$ & $-1[-\mathrm{H}]$ \\
\hline PS & $+1[+\mathrm{H}]$ & $-1[-\mathrm{H}]$ \\
\hline LPS & $+1[+\mathrm{H}]$ & $-1[-\mathrm{H}]$ \\
\hline S1P & $+1[+\mathrm{H}]$ & $+45[+\mathrm{HCOO}]$ \\
\hline
\end{tabular}

\section{$2 \cdot 7$ 試料の分析手法}

リピドミクスにおいては, 測定対象の広さ, より微量 のものを検出できる感度, 特定の構造特性をもつという 種々の観点から, 目的別の異なった解析手法が必要であ る。以下に 3 種類の解析法の詳細を解説する。

\section{$2 \cdot 7 \cdot 1$ 対象を絞らないグローバル解析法}

まず，1番目は特定の分子群に限定せずに，LCによ り分離溶出された分子を，イオン強度の高い順にできる だけすべて MS 又は MS/MS 測定するという包括的な手 法があげられる。この手法は前述している順相または逆 相 LC 条件を用いて分離してくるプレカーサーイオンを とりこぼしなく測定するため，脂質全体をプロファイリ ングし変動を包括的に解析するのに適している。その分 析にはスキャンスピードが速く, MS/MS 解析が可能な 四重極－TOF のハイブリッド型 MS や, 四重極一イオ ントラップのハイブリッド型 MS が有効とされる。また, data dependent scan 法によりプレカーサーイオン分析
と同時にイオン強度の高い順に自動 MS/MS 分析するこ とで, 分子種の同定が可能であるが, MS/MS で同定出 来る分子種は含量の多い代謝物に限定されるので, 微量 成分を検出するには LC 分析の前に主要成分と微量成分 を分離する等の前処理が重要である ${ }^{5-7)}$ 。一方で, MS/ MS 分析のできないシングル質量分析計でもイオン化の 際にかける電圧を制御することでインソースコリジョン を利用したプロダクトイオンの情報を得る（MS/MS 分 析ではないため安定したプロダクトイオンは得られにく い）ことができ，お执よその分子種の推定が目的であれ ば十分に実用可能である。

グローバル解析法はオミクス解析の目的に適ってお り，予想していない新たな分子を発見する可能性を増大 させる。しかし, その一方で短所として, 生理活性脂質 などの微量な生体重要分子の存在を見逃すという問題も ある。最近では微量成分の分析として MS/MS 分析の際 に閾值を設定せずに測定できる装置も販売されている が，まだまだすべてのリン脂質を網羅するには課題が残 されている。そこで, リピドミクスではターゲットを定 めない包括的 - 網羅的分析手法とは別に, 特定の脂質分 子群にフォーカスする手法や個別分子にターゲットをお いて分析することが重要となってきている。

\section{$2 \cdot 7 \cdot 2$ 特定の分子群へのフォーカス解析法}

2 番目の手法は, 特異的な部分構造にフォーカした同 定法である。トリプルステージ型質量分析計の測定手法 であるプレカーサーイオンスキャン（Pre）やニュート ラルロススキャン（NL）を用いて，特定な部分構造を 持つグループに属する分子群を選択的，かつ包括的に同 定する手法である ${ }^{8-10)}$ 。リン脂質分析では, 構造特異性 を生かすことで特定の極性基や脂肪鎖を持つ分子種ごと に分類して測定を行う。Positive ion modeでは, PCは コリンリン酸 $(m / z 184)$ のPre, PEはエタノールア ミンリン酸 $(141 \mathrm{u})$ の NL, PS はセリンリン酸（185u） の NL，PI はアンモニアとイノシトールリン酸 $(277 \mathrm{u})$ の NLを行い, negative ion modeでは，PCはギ酸とメ チル（60u）の NL, PE はサイクリックグリセロエタノー ルアミンリン酸 $(m / z$ 196) の Pre, PS はセリン (87u) の NL, PI はサイクリックイノシトールリン酸 $(m / z$ 241)のPre を行う。この手法では, LCを用いずにフロー インジェクションでも主要な分子群を同定でき, LC と 組み合わせた解析では溶出時間情報とイオン抑制の減少 により高精度, 高感度な同定と変動解析が可能である。

\section{$2 \cdot 7 \cdot 3$ 特異的なターゲット解析法}

さらに第 3 の手法は, 特定分子種分子を対象とした個 別かつ特異的同定法である。これは特定の $m / z$ 值をも つプレカーサーイオンと特徵的なフラグメントイオンの 
$m / z$ 值を組み合わせた多重/選択反応モニタリング （MRM, SRM）と呼ばれる手法である。検出感度が高く， 定量法としても用いることができる。また，この手法は 特異性の高さから生体内に存在が示唆されていない分子 に対してもプレカーサーイオンと特徴的フラグメントイ オンの組み合わせを，構造相関を基にあらかじめ理論的 に推察することで新たな分子を探索する目的で使用され る。この測定法は predicted-MRM/-SRM と呼ばれてい る。

\section{$2 \cdot 8$ 解析手法}

生体分子を網羅的に解析するオミクス解析には，その 膨大な実験情報を効率的に処理するため, バイオイン フォマティクスと呼ばれる生体情報処理が必須な技術と なっている。例えばプロテオミクスでは, NCBIや UniProt などのデータベースやタンパク質同定ソフト ウェアMascot などの豊富な解析用ソフトウェアが開発 されており，ハイスループットな解析を行う環境が整備 されている。一方, リピドミクスにおいては LipidBank や LipidMap, さらには MassBankなどといったデータ ベースの整備は進みつつあるものの, 解析用ソフトウェ アに関しては依然発展途上である。現在，脂質同定用の ソフトウェアとして著者が有効だと思うものに，東京大 学の田口良先生（現，中部大学） と三井情報株式会社と が共同作製したLipid Search と，AB Sciex 社の Lipid Viewerの 2 つが挙げられる。著者個人としてはいくつ かの改良希望があるものの，ともに同定に必要な拡張さ れた検索エンジンを含む効率的なソフトウェアである。 さらに，同定・未同定に関わらず，膨大なデータから価 值のあるもの，パターンを見つける目的としてデータマ イニングやビジュアライゼーションは, リピドミクスに おいて必須の解析項目となりつつある。MSの販売元を 含め, 最近では多くのメーカーから統計解析, 生物学的 解析など様々な機能を有するデータマイニングソフト ウェアや，デー夕解釈のための多様なビジュアライズ機 能を有するソフトウェアが販売されている。

\section{3 医療応用への期待と課題}

高齢化が進む社会の中，生活習慣病をはじめとした多 くの疾患に新しい原理に基づく早期診断法や医薬の開発 が求められている。脂質と医薬品との関わりでいえば, 長年世界中で使用されているメバロチンやアスピリン等 の薬剂は脂質代謝酵素を作用点とし, モンテルカスト (抗 喘息）やフィンゴリモイド（抗多発性硬化症）といった 新薬は脂質受容体を標的としたもので，本邦には脂質関 連創薬に実績をもつ製薬企業が多い。さらに，脂質代謝 異常に起因する疾患は有病者数が年々増加の一途をた
どっていることから今後も脂質をターゲットとした創薬 開発は必須となる。このなか, 我が国の第 4 期科学技術 基本計画の中に「新しい早期診断法の開発」として,「早 期診断に資する微量物質の同定技術等の新たな検出法と 検出機器の開発，新たなマーカーの探索や同定など，精 度の高い早期診断技術の開発を推進する」ことが挙げら れた。つまり，脂質を含む生体内代謝物は，ゲノム情報 の最終的な表現型であり病態を反映することから，その 分析技術となるリピドミクス解析の進展 · 整備は早急に 着手すべき重要課題である。しかし, リピドミクスの解 析基盤は十分確立しきれておらず，世界共有の分析法は いまだ存在していない。さらに, 多くの分析法は基礎研 究のなかで構築されたもので, ヒト検体での実績は少な く, 試料採取から前処理, さらには分析法の真度, 精度, 信頼性などをヒト検体用にバリデーションし直さなけれ ばいけないのが現状である。著者らも多くの病院や製薬 企業と医療応用に向けて取り組んでいる最中である。

\section{4 おわりに}

脂質はその水に溶けない物性，ゲノムに直接コードさ れない理由から, 科学技術が進歩した現在でも解析し難 い対象であり，また，このことが多くの脂質機能が未解 明のまま残されている一因となっている。近年の脂質分 析技術（リピドミクス解析）進歩はリピドーム研究に大 きなインパクトを与えた。すなわち質量分析機器を用い た分析技術の革命は，「これまで解析されてきた脂質分 子は氷山の一角に過ぎず，生体内にはゲノムの数をはる かに凌ぐ種類の脂質が存在する」可能性を示した。脂質 は，遺伝子， タンパク質に比肩するバイオリソースであ る。つまり、リピドミクスを軸としたリピドーム研究の 進展は，新たな医薬や機能性食品の創製へと繋がる可能 性が高く, 経済的・産業的に大きな波及効果が期待され る。また, 疾患マーカー脂質の発見や早期診断法の確立, ドラッグデリバリーにおけるリポソームの活用など，脂 質デイバイスの活用も大いに期待される。

専門知識が必要とされるリピドミクス解析の技術者数 は, リピドーム研究者のなかでもまだまだ一握りであ る。今後, 技術の発展とともに汎用性の高いものとして リピドミクス解析が一般手法化され, 多くの研究者に扱 われる日がくることを期待したい。

\section{文 献}

1) M. Ishida, M. Imagawa, T. Shimizu \& R. Taguchi, $J$. Mass Spectrom. Soc. Jpn., 53, 217 (2005).

2) 日本分析化学会編, 試料分析講座 脂質分析, 丸善出版, p.11 (2011).

3）宮澤陽夫，藤野康朗 編集，生物化学実験法 9 「脂質 · 
酸化脂質分析法入門」, 学会出版センター, p.44 (2000).

4）清水孝雄 編集, わかる実験医学シリーズ 脂質生物学 がわかる，羊土社，p.28（2004）.

5) D. Schwudke, G. Liebisch, R. Herzog, G. Schmitz \& A. Shevchenko, Methods Enzymol., 433, 175 (2007).

6) K. Yang, Z. Zhao, R. W. Gross \& X. Han, PLoS ONE, 2, e1368 (2007).

7) T. Houjou, K. Yamatani, M. Imagawa, T. Shimizu \& R. Taguchi, Rapid Commun. Mass Spectrom., 19, 654
(2005).

8) T. Houjou, K. Yamatani, H. Nakanishi, M. Imagawa, T. Shimizu \& R. Taguchi, Rapid Commun. Mass Spectrom., 18, 3123 (2004).

9) R. Taguchi, T. Houjou, H. Nakanishi, T. Yamazaki, M. Ishida, M. Imagawa \& T. Shimizu J. Chromatogr. B, 823, 26 (2005).

10) K. Ekroos, I. V. Chernushevich, K. Simons \& A. Shevchenko, Anal. Chem., 74, 941 (2002). 